\title{
PENDIDIKAN PERSPEKTIF GENDER DI INDONESIA (Menimbang dan Menakar Peran Gender dalam Pendidikan)
}

\author{
Syamsun Ni'am \\ Jurusan Tarbiyah STAIN Jember \\ E-mail:niam_789@gmail.com
}

\begin{abstract}
The development of education in Indonesia in its growth, have shown repair symptom from time to time, but society view about gender in reality is can not be changed and altered quickly. The strength of value system and culture construction which not represent gender equality yet is have an effect to school education pattern. Participation number, graduation number, majors choices, and possibility acces to work after graduate from school express how highly awareness of society about the important of gender equality. As long as culture construction of society still differentiate the role and the position of man and woman, as long as also its influence to form and pattern of school education. Perhaps need long time to fight for gender equality and justice in education.

Pembangunan pendidikan di Indonesia dalam perkembangannya, telah menampakkan gejala perbaikan dari waktu ke waktu, namun pandangan masyarakat terhadap gender ternyata tidak begitu cepat dapat berubah dan diubah. Kuatnya sistem nilai dan konstruk budaya yang belum merepresentasikan kesetaraan gender turut berpengaruh terhadap pola pendidikan persekolahan. Angka partisipasi, angka kelulusan, pilihan jurusan dan program studi, serta kemungkinan akses terhadap pekerjaan setelah tamat dari sekolah mencerminkan seberapa tinggi kesadaran masyarakat mengenai perlunya kesetaraan gender. Sepanjang konstruk budaya masyarakat masih membedakan peran dan posisi anak laki-laki dan perempuan, sepanjang itu pula pengaruhnya terhadap bentuk dan pola pendidikan persekolahan. Barangkali butuh waktu panjang untuk memperjuangkan kesetaraan dan keadilan gender dalam pendidikan
\end{abstract}

Keyword: Kesetaraan Gender dan Pendidikan

\section{Pendahuluan}

Wacana kesetaraan gender telah benar-benar mengemuka seiring dengan munculnya tuntutan untuk mendapatkan perlakuan sama tidak hanya pada urusan-urusan domestik, namun juga menyangkut urusan publik. Hal ini terjadi sebagai konsekuensi logis dari berkembangnya tidak hanya pada tingkat kualitas intelektual kaum perempuan, namun juga ditentukan oleh tingkat kebutuhan dan tuntutan masyarakat secara menyeluruh demi perimbangan pengembangan dan pembangunan di segala bidang. Pada saat sekarang, tidak sedikit kaum perempuan yang berani menyuarakan hak-hak dan kepentingannya sebagai warga masyarakat yang mestinya mendapat perlakuan dan kedudukan sama dalam pembangunan, yang dulunya hal tersebut merupakan hal tabu untuk diperbincangkan. Namun seiring dengan perjalanan waktu, konstruk budaya patriarkhi tersebut sedikit demi sedikit telah mengalami reduksi. Oleh karena itu, tidaklah benar jika peran kaum perempuan harus dibatasi dalam ruang geraknya yang sempit, baik pada ranah politik, ekonomi, sosial-budaya, maupun pendidikan sekalipun.

Terkait dengan hal di atas, Human Development Report (HDR) pernah melaporkan, bahwa "Kesetaraan gender merupakan inti yang menentukan pencapaian Millenium Development Goal (MDG), mulai dari peningkatan derajat kesehatan dan memberantas penyakit, sampai ke penghapusan kemiskinan dan kelaparan, memperluas pendidikan dan mengurangi angka kematian bayi dan balita, 
memperluas akses kepada air bersih dan menjamin keberlanjutan lingkungan". Kalimat tersebut ditulis dengan huruf dalam ukuran yang lebih besar, mengisi "jendela" Laporan Pembangunan Manusia (Human Development Report, HDR) tahun 2003. HDR 2003 secara eksplisit menyatakan, kalau tidak ada kemajuan dalam pemberdayaan perempuan dan kesetaraan gender, MDG tidak akan bisa dicapai. (Kompas, 14 Juli 2003)

Laporan tersebut menyebutkan bahwa pendidikan sebagai target resmi MDG untuk melihat kemajuan atas tujuan kesetaraan gender. Dalam laporan itu dinyatakan, bahwa disparitas gender harus dihapuskan di tingkat pendidikan dasar dan menengah kalau mungkin pada tahun 2005, dan di seluruh tingkat pendidikan pada tahun 2015. Beberapa indikator untuk memantau kinerja itu sudah dirumuskan yaitu rasio anak perempuan di dalam pendidikan dasar, menengah, dan tinggi; rasio melek huruf antara perempuan dan laki-laki antara usia 15-24 tahun; jumlah perempuan di pasar kerja, di luar sektor pertanian; dan jumlah perempuan di parlemen, baik tingkat nasional maupun lokal. Asumsi yang dikembangkan adalah kesetaraan gender di bidang pendidikan akan membantu perempuan mengamankan pekerjaan mereka di luar rumah dan mendapatkan ruang luas di wilayah politik, serta memberikan sumbangan kepada kelembagaan di ruang publik.

Sebagai salah satu negara penandatangan MDG, Indonesia -di antara 175 negara yang ikut menandatangani MDG terikat untuk merumuskan secara tepat pembangunan yang berkeadilan gender. Bersamaan dengan program Pengarusutamaan Gender bidang pendidikan yang digalakkan sejak tahun 2000, pemerintah tampaknya serius mengembangkan pembangunan yang sensitif gender, sebagai bagian dari indikator HDI (Human Development Indext). Disparitas gender pada tingkat dasar dan menengah yang harus dicapai tahun 2005, misalnya, menurut Fasli Jalal, Dirjen Pendidikan Luar Sekolah dan Pemuda Depdiknas, sudah tercapai tahun 2005 ini. Bahkan Fasli Jalal menyebut MDG Indonesia relatif lebih baik dari negara-negara berkembang di Asia Selatan.

Mengacu pada MDG tersebut, ulasan di bawah akan mencoba melihat sejauhmana indikatorindikator lain sudah tercapai. Uraian dimulai dari tilikan tentang urgensi dan signifikansi pendidikan bagi perempuan, pendidikan untuk perempuan; sebuah pilihan gender, dan realitas kesetaraan gender dalam pendidikan.

\section{Urgensi dan Signifikansi Pendidikan bagi Perempuan}

Perbincangan tentang urgensi dan signifikansi pendidikan bagi perempuan telah dimulai sejak 1970-an pada saat kalangan feminis mengkritik model pembangunan yang merugikan perempuan. Adalah E. Boserup (1970) yang seringkali disebut sebagai pelopor kritik ini dalam bukunya Women's Role in Economic Development. Boserup menyatakan bahwa pendidikan perempuan mampu mengeliminir dampak negatif dari pembangunan ekonomi, karena pendidikan paling tidak bisa menambah akses perempuan terhadap pasar kerja dan memperbaiki keahlian (skill) tertentu.( E. Boserup, 1984) Di tengah kuatnya ideologi developmentalisme yang digandrungi negara-negara berkembang, termasuk Indonesia, kritik Boserup ini terasa menggigit. Sejak kritik itu dilontarkan, studi Boserup menjadi offspring (bibit) bagi studi-studi lain tentang isu pendidikan perempuan yang umumnya menunjukkan hubungan yang signifikan dengan indikator kesejahteraan sosial seperti angkatan kerja perempuan, tingkat kesuburan, tingkat kematian, dan tingkat usia hidup sejak lahir. (Nurul Azkiyah, 2004)

Mengacu pada temuan dalam studi-studi tentang perempuan dan pembangunan, tidak heran kalau perluasan akses perempuan terhadap pendidikan menjadi kebijakan utama di beberapa negara berkembang sejak tiga dasawarsa lalu. Sebagai contoh kasus di Indonesia, ideologi 'pembangunanisme' yang dilancarkan Orde Baru sejak 1970-an jelas-jelas berpengaruh amat kuat terhadap dunia pendidikan. Berkat pertumbuhan ekonomi yang tinggi, terutama karena melonjaknya harga minyak (oil boom) pada akhir 1973, pemerintah Orde Baru telah mampu membiayai perkembangan yang pesat sekolah-sekolah dasar dan sebagian sekolah menengah. Sebagaimana dikemukakan Arya B. Gaduh, tahun 1971-1981 merupakan periode pertumbuhan ekonomi amat pesat, rata-rata 7,7 persen. Pertumbuhan ekonomi dalam periode ini terutama didorong oleh lonjakan 
harga minyak dunia pada akhir 1973, yang memberikan dana segar bagi pemerintah untuk melaksanakan pembangunan. Pemerintah segera meningkatkan alokasi anggaran untuk pengeluaran pembangunan, melonjak dari sekitar 20 persen pada tahun 1968 menjadi 56 persen tahun 1976. Di bidang pendidikan, gebrakan pertama pemerintah adalah dengan menerbitkan Instruksi Presiden (Inpres) No. 10/1973 yang bertujuan membangun sekolah-sekolah dasar (SD) dan fasilitas pendukungnya lebih dari 60.000 desa di seluruh Indonesia. (Budhisastra Gaduh, 2000)

Hasil dari kebijakan tersebut memang cukup mengesankan. Jika pada tahun 1968 angka partisipasi pendidikan untuk penduduk usia 7-12 tahun hanya sekitar 41 persen, pada akhir Pelita Ketiga (1983/4) angka tersebut melonjak tajam mencapai lebih dari 97 persen. (HAR Tilaar, 1995) Artinya, hanya dalam tempo satu dasawarsa sejak dimulainya Program Inpres, angka partisipasi kasar (APK) pendidikan tingkat SD universal sudah tercapai 100 persen. Optimisme inilah yang menjadi dasar pencanangan program "wajib belajar" tingkat SD (Wajar 6 Tahun) oleh Presiden Soeharto pada Mei 1984.

Peningkatan partisipasi pendidikan (APK) pada semua jenjang merupakan indikasi positif kemajuan pendidikan selama kurun 1970 hingga 1983/4. Kebijakan yang ditempuh pemerintah pun cukup tepat, yakni memulai pembangunan pendidikan dari jenjang yang paling bawah. Ini bisa dilihat dari cara penggunaan anggaran pendidikan yang biasanya mengalokasikan sekitar 50 persen untuk pendidikan primer (tingkat SD), dan hanya sekitar 14 persen masing-masing untuk pendidikan setingkat SLTP, SLTA, dan Perguruan Tinggi. Hasil dari kebijakan tersebut adalah tercapainya pendidikan tingkat SD universal di Indonesia di tahun 1983, serta meningkatnya APK pada jenjang pendidikan lainnya (Tabel 1). Pada tingkat SLTP, APK melonjak dari 16,9 persen pada tahun 1970 menjadi 66,7 persen pada tahun 1994. APK tingkat SLTA juga menunjukkan kenaikan dari 8,6 persen pada tahun 1970 menjadi 45,1 persen pada tahun 1994. Sementara tingkat Perguruan Tinggi, APK meningkat dari sekitar 2 persen pada tahun 1974 menjadi 11 persen di tahun 1994.

Tabel 1

Angka Partisipasi Kasar (APK 1969-1994)

\begin{tabular}{||l|c|c|c|c|c|c||}
\hline $\begin{array}{c}\text { Jenjang } \\
\text { Pendidikan }\end{array}$ & $1969 / 70$ & $\begin{array}{c}\text { Akhir } \\
\text { Pelita I } \\
(1973 / 4)\end{array}$ & $\begin{array}{c}\text { Akhir } \\
\text { Pelita II } \\
(1978 / 9)\end{array}$ & $\begin{array}{c}\text { Akhir } \\
\text { Pelita III } \\
(1983 / 4)\end{array}$ & $\begin{array}{c}\text { Akhir } \\
\text { Pelita IV } \\
(1988 / 9)\end{array}$ & $\begin{array}{c}\text { Akhir } \\
\text { Pelita V } \\
(1993 / 4)\end{array}$ \\
\hline SD*) & 64 & 66,5 & 97,2 & 99,5 & 99,6 & 99,7 \\
\hline SLTP & 16,9 & 17,4 & 27,7 & 44 & 53,4 & 66,7 \\
\hline SLTA & 8,6 & 9,3 & 26,1 & 26,1 & 36,6 & 45,1 \\
\hline PT & - & 1,9 & 5,3 & 5,3 & 8,5 & 11 \\
\hline
\end{tabular}

Catatan: *) Angka Partisipasi Bersih (APB)

Sumber : Tilaar (1995)

Selain peningkatan partisipasi pendidikan, pencapaian yang tidak kalah pentingnya adalah penghapusan buta huruf. Tabel 2 menggambarkan perkembangan persentase jumlah penduduk yang melek huruf antara tahun 1971-1990. Data ini menunjukkan bahwa di tahun 1990 hampir seluruh penduduk usia muda tidak lagi buta huruf dan lebih dari 70 persen penduduk pada usia lainnya, kecuali kelompok yang paling tua, mampu membaca dan menulis. (Misi Bank Dunia (World Bank Report), 1996). 
Tabel 2

Persentase Penduduk Yang Bisa Baca Tulis

Berdasarkan Kelompok Umur, 1971-1990

\begin{tabular}{|l|c|c|c|}
\hline \multicolumn{1}{|c|}{ Umur } & 1971 & 1980 & 1990 \\
\hline 15-24 Tahun & 80,1 & 85,4 & 94,7 \\
\hline 25-34 Tahun & 61,9 & 77,7 & 89 \\
\hline 35-44 Tahun & 47,8 & 62 & 70,9 \\
\hline 45 Tahun + & 31,1 & 39,7 & 58,8 \\
\hline
\end{tabular}

Sumber: BPS, dikutip dari Hill (1996)

Dari jumlah penduduk yang melek huruf tersebut, posisi kaum perempuan menunjukkan perbaikan. Arya B Gaduh yang mengutip studi CSIS tahun 1999 menyajikan data bahwa jumlah perempuan usia 7-12 tahun yang bersekolah meningkat drastis dari hanya 5,7 juta orang tahun 1971 menjadi 12,1 juta orang tahun 1985. Pada tahun yang sama angka partisipasi pendidikan pada semua tingkat usia pendidikan tampak cukup signifikan. Fakta ini mengakibatkan perbedaan APK antar gender semakin mengecil, dan dengan begitu terjadi keseimbangan gender (gender parity).

Tabel 3

Angka Partisipasi Pendidikan Bersih Perempuan

Berdasarkan Umur dan Tempat Tinggal, 1971-1985 (dalam persen)

\begin{tabular}{|c|c|c|c|c|c|c|c|c|c|}
\hline \multirow{2}{*}{ Umur } & \multicolumn{3}{|c|}{ Perkotaan } & \multicolumn{3}{c|}{ Pedesaan } & \multicolumn{3}{c|}{ Total } \\
\cline { 2 - 12 } & 1971 & 1980 & 1985 & 1971 & 1980 & 1985 & 1971 & 1980 & 1985 \\
\hline $7-12$ & 72 & 91 & 96 & 55 & 81 & 93 & 58 & 83 & 94 \\
\hline $13-15$ & 57 & 72 & 83 & 34 & 50 & 65 & 39 & 56 & 70 \\
\hline $14-18$ & 34 & 45 & 63 & 11 & 16 & 31 & 15 & 24 & 41 \\
\hline
\end{tabular}

Sumber: Oey-Gardined (1991), sebagaimana dikutip Gaduh, Analisis CSIS 3/2000

Semakin kecilnya perbedaan antar gender dalam partisipasi sekolah memberikan indikasi bahwa orang tua menganggap pendidikan anak perempuan sama pentingnya dengan pendidikan anak laki-laki. Laporan World Bank 1998 semakin memperjelas kenyataan ini. Para orang tua di Indonesia ternyata mengeluarkan biaya yang sama untuk pendidikan bagi anak laki-laki dan perempuan mereka pada tingkat SD dan SMP, dan justru mengeluarkan biaya lebih besar untuk pendidikan di atas SMU bagi anak-anak perempuan dibandingkan dengan anak laki-laki mereka.

Hasil-hasil kebijakan pendidikan selama masa Orde Baru seperti diuraikan di atas, menjelaskan bahwa dekade 1971 hingga 1984 dapat dianggap cerita sukses (success story) bagi pendidikan di Indonesia. Tetapi tidak lama setelah itu, kurun antara 1985-1990 merupakan masa-masa sulit bagi dunia pendidikan. Bersamaan dengan merosotnya harga minyak dunia sejak tahun 1982, pertumbuhan ekonomi nasional mulai melambat. Pada tahun 1986, ketika harga minyak jatuh secara lebih tajam, pendidikan menjadi salah satu sektor yang harus mengalami pemotongan anggaran secara signifikan bukan hanya dalam nilai absolut, tetapi juga relatif terhadap Produk Domestik Bruto (PDB) dan anggaran total pemerintah. Antara 1985-1990, anggaran pendidikan sebagai presentase terhadap PDB menurun drastis dari 4,1 persen menjadi 2,8 persen. Sementara dari persentase terhadap total anggaran pemerintah, alokasi yang sebelumnya mencapai 17,6 persen pada 1985 menurun pada 1990 menjadi 11,8 persen. Meskipun rata-rata pertumbuhan ekonomi sempat membaik antara 1987-1992, anggaran 
pendidikan relatif terhadap total anggaran tetap tidak beranjak dan/atau lebih baik dari kondisi tahun 1985.

Meski demikian, studi Azkiyah memperlihatkan bahwa selama 10 tahun (1980-1990) angka masuk siswa perempuan pada tingkat SD mencapai 10.602 .609 (49,18\% dibanding laki-laki), sedangkan siswa laki-laki adalah 11.073 .517 (50,83\% dibanding perempuan). Pada jangka tahun yang sama, di tingkat SMP, angka masuk siswa perempuan turun menjadi 46,34\% (3.391.344) berbanding 53,56\% (3.900.376) untuk laki-laki. Di tingkat SLTA angka masuk perempuan maupun laki-laki turun lebih jauh lagi dengan perbandingan angka masuk perempuan 1.668.270 (41,45\%) dan laki-laki mencapai 2.289.059 (58.57\%). (Azkiyah, 2002).

Studi itu menyimpulkan bahwa angka masuk perempuan selalu lebih rendah dalam semua tingkat dan jenjang pendidikan. Selain itu, semakin tinggi tingkat pendidikan, semakin jauh angka masuk perempuan di bawah laki-laki dan semakin mengecil juga prosentasenya dibanding laki-laki. (Evelyn Suleeman, 1995) Ini menunjukkan bahwa semakin tinggi tingkat pendidikan, semakin besar tingkat disparitas (ketidakseimbangan) gendernya. Di samping itu, data ini menyiratkan bahwa kesempatan untuk akses pendidikan lebih banyak terbuka bagi anak laki-laki ketimbang anak perempuan. Bagaimana itu terjadi? Mengapa data ini bertentangan dengan laporan World Bank?

Ada berbagai sebab mengapa disparitas gender dalam kuantitas dan jenjang pendidikan itu melebar. Sebab-sebab yang menonjol tampaknya berkisar pada berkurangnya subsidi pemerintah untuk sekolah-sekolah karena menurunnya anggaran relatif dan mengecilnya dukungan masyarakat akibat menurunnya tingkat ekonomi atau memburuknya pemasukan riil dan exchange entitlement masyarakat. Kemampuan ekonomi sering menjadi kendala bagi orang tua, terutama dan apalagi di pedesaan, untuk menyekolahkan anak ke tingkat yang lebih tinggi. Dalam situasi seperti itu biasanya anak perempuan dirugikan karena prioritas pendidikan seringkali diberikan kepada anak laki-laki. Pertimbangannya, anak laki-laki adalah tulang punggung keluarga yang diharapkan dapat membantu orang tua dan adik-adiknya kelak kalau sudah berkerja. Adapun anak perempuan masih ada kemungkinan bergantung kepada suaminya kelak, dan akibatnya pendidikan bagi mereka mendapat prioritas ke sekian. (Apriadi, 2001).

Alasan lain mengapa disparitas itu terjadi, secara singkat dapat disebutkan, antara lain: pertama, semakin tinggi tingkat pendidikan, semakin terbatas jumlah sekolah yang tersedia. SD terdapat di hampir semua desa di Indonesia, maka seorang murid SD tidak perlu keluar desa untuk pergi ke sekolah. Tetapi seorang murid harus menempuh perjalanan yang lebih jauh bila ia bersekolah di SLTP, apalagi untuk tingkat SLTA yang umumnya masih terkonsentrasi di kota. Dalam konteks ini banyak orang tua yang enggan bila anak perempuan mereka pergi ke sekolah yang jauh karena alasan keamanan ataupun kehilangan bantuan tenaga kerja.

Kedua, semakin tinggi tingkat pendidikan, semakin mahal biaya yang harus dikeluarkan. Besarnya ongkos sekolah ini menjadi hambatan, terutama bagi keluarga miskin. Faktor ketiga, prioritas pendidikan pada laki-laki sangat dipengaruhi oleh konstruksi gender yang berlaku di masyarakat. Masyarakat masih memandang anak perempuan tidak perlu sekolah tinggi-tinggi karena toh mereka akan menjadi istri, ibu dari anak-anak yang akan dilahirkan, dan bertalian dengan pekerjaan-pekerjaan domestik yang tidak memerlukan kecanggihan pemikiran. Konstruk budaya ini menjadikan anak perempuan terbatasi dengan sendirinya dalam memperoleh akses pendidikan yang lebih baik.

Jika dibandingkan dengan data Bappenas, penurunan jumlah penduduk yang buta huruf menyebabkan peningkatan angka melek huruf. Pada 1980, berdasarkan data Bappenas, perempuan yang melek huruf mencapai $63 \%$, jauh dibandingkan laki-laki yang mencapai $80 \%$. Sepuluh tahun kemudian persentase melek huruf untuk perempuan meningkat menjadi $79 \%$ dan laki-laki menjadi 90\%. Pada akhir pemerintahan Orde Baru, 1998, kesenjangan melek huruf antara laki-laki dan perempuan semakin mengecil, yakni laki-laki $93,4 \%$ dan perempuan $85,5 \%$. Meskipun demikian, secara kuantitas masih terdapat 11,7 juta perempuan yang buta huruf dibandingkan dengan 5,2 juta 
laki-laki. Artinya, tingkat melek huruf secara nasional masih ada perbedaan antara laki-laki dan perempuan.

Data-data tersebut mengindikasikan satu hal: bahwa naiknya angka melek huruf berkaitan dan merupakan kelanjutan dari bertambahnya angka partisipasi pendidikan baik laki-laki maupun perempuan. Akan tetapi, indikasi ini menegaskan hal lain: bahwa pendidikan signifikan untuk membangun kemampuan baca (literate) yang merupakan salah satu skill dasar dan penting yang harus dikuasai oleh setiap individu. Kemampuan baca akan membantu setiap orang untuk mentransformasikan dan mendapatkan pengetahuan serta pengalaman yang diperlukan bagi kooperasi sosial. Dalam perspektif ini, penting ditekankan perlunya mengembangkan pendidikan perempuan untuk memperbaiki tingkat melek huruf perempuan. Apalagi jumlah penduduk perempuan yang mencapai lebih 50\% sangat substansial untuk membangun struktur dan kualitas penduduk apabila mereka memperoleh pendidikan yang memberdayakan.

Dampak ikutan (nurturant effect) lebih lanjut dari semakin bertambahnya perempuan masuk dalam jenjang pendidikan yang lebih tinggi adalah terbukanya peluang kerja profesional dan teknis bagi perempuan. Studi Azkiyah lagi-lagi penting dikemukakan. Pada tahun 1993-1998 pekerja profesional dan teknis perempuan bertambah sebanyak 2,5\%, meskipun sebenarnya kenaikannya hanya terjadi pada 1999. Tahun 1998 sempat terjadi stagnasi akibat gelombang reformasi yang mengakibatkan banyak kesulitan bagi perempuan untuk meniti karir pekerjaan. Meskipun pendidikan bukan satu-satunya faktor dalam mendapatkan pekerjaan dan posisi yang lebih baik - faktor lain seperti lapangan kerja, pengalaman kerja, dan relasi terbukti cukup berpengaruh - tetapi dengan pendidikan akan semakin luas jenis pekerjaan yang bisa dimasuki oleh perempuan.

Demikian juga dapat dilaporkan tentang perempuan yang bekerja di instansi pemerintahan (PNS). Pada 1993 perempuan yang bekerja di sektor pemerintahan ditengarai semakin bertambah. Meskipun masih terjadi discrepancy, kesenjangan antara jumlah perempuan yang bekerja di sektor ini dibandingkan dengan laki-laki, kecenderungan sejak tahun 1993 menunjukkan gelagat yang membaik dilihat dari sektor pendidikan perempuan. Tabel di bawah ini menunjukkan bahwa hingga 1995 (berdasarkan BPS) kesenjangan gender masih terjadi di beberapa departemen dan kantor nondepartemen.

Tabel 4: Perbandingan Laki-laki dan Perempuan di Beberapa

Kantor Pemerintahan, 1995 (dalam \%)

\begin{tabular}{|c|l|c|c|}
\hline NO & \multicolumn{1}{|c|}{ KANTOR PEMERINTAHAN } & PEREMPUAN & LAKI-LAKI \\
\hline 1 & Departemen Kesehatan & 54 & 46 \\
\hline 2 & Departemen Pendidikan dan Kebudayaan & 37 & 63 \\
\hline 3 & Perpustakaan Nasional & 43 & 57 \\
\hline 4 & BKKBN & 37 & 63 \\
\hline 5 & Departemen Sosial & 35 & 65 \\
\hline 6 & Departemen Pertanian & 8 & 92 \\
\hline 7 & Departemen Pekerjaan Umum & 11 & 89 \\
\hline 8 & Departemen Perhubungan & 11 & 89 \\
\hline 9 & Kementerian Ristek & 13 & 87 \\
\hline 10 & Departemen Hankam & 15 & 85 \\
\hline
\end{tabular}

Diadaptasi dari BPS, 1995 tentang "Perempuan dan Laki-Laki di Indonesia".

Data di atas menunjukkan bahwa di kantor-kantor departemen gender disparity masih besar. Hal ini kemungkinan besar karena seleksi dan proses rekruitmen karyawan tidak sensitif gender. Kemungkinan lain karena kesempatan perempuan pada bidang ini masih terbatas, atau SDM perempuan yang belum tersedia. Mesipun ada kesenjangan dalam jumlah, Ace \& Idris memberi data bahwa tidak ada kesenjangan gender dalam sistem pengupahan di sektor pemerintahan. Pemerintah memberlakukan standar gaji/upah berdasarkan golongan/pangkat dan masa kerja dengan jumlah dan nominal yang sama baik bagi laki-laki maupun perempuan. Hanya persoalan muncul berkaitan 
dengan: seberapa besar peran, jumlah, dan keterlibatan perempuan yang menjadi PNS sehingga turut dalam membuat dan mengambil keputusan. Data pada tahun 2000 (lihat grafik 1) menunjukkan bahwa kaum perempuan yang menjadi PNS sudah ada pada semua tingkatan dan golongan kepangkatan, tetapi proporsinya sangat tidak seimbang. Pada pos-pos tertentu bahkan perempuan menempati posisi periferal.

Seluruh data di atas memberi gambaran bahwa pendidikan menentukan seberapa besar harapan dan capaian perempuan dalam wilayah publik. Dengan kata lain, pendidikan adalah "jembatan mobilitas" yang paling mungkin dilalui jika perempuan ingin melakukan perbaikan baik pada aras kognitif (pengetahuan dan penguasaan ilmu/teknologi) maupun praktis (pekerjaan). Terbukanya ruang mobilitas yang semakin besar bagi perempuan (sebagai warga negara) sangat menentukan arah pencapaian pembangunan sebuah bangsa. Dengan semakin terbukanya akses sosial dan ekonomi bagi perempuan, pada gilirannya perbaikan akses pendidikan perempuan akan berkorelasi dengan peraihan dan capaian-capaian di bidang politik. Ditetapkannya kuota $30 \%$ bagi perempuan di parlemen (sebagai impementasi UU Pemilu) merupakan contoh semakin kuatnya daya tawar (bargaining position) perempuan dalam wilayah publik. Dalam kata-kata bijak Kartini, pendidikan sekolah pada akhirnya dapat menetralisir perbedaan kelelakian dan keperempuanan yang merupakan bentukan budaya itu, "bahwa kita dapat menjadi manusia sepenuhnya, tanpa berhenti menjadi wanita sepenuhnya".

\section{Pendidikan untuk Perempuan; Sebuah Pilihan Gender}

Salah satu persoalan gender dalam dunia pendidikan yang sering menjadi sasaran kritik adalah pilihan pendidikan untuk anak perempuan yang bertali-temali dengan faktor persepsi gender (budaya). Asumsi yang berkembang bahwa jenis pendidikan yang dipilih -atau dipilihkan untuk - perempuan adalah yang menunjang atau berdekatan dengan peran-peran domestik, seperti guru, sekretaris, dokter, bidan, juru rawat, pekerja sosial, seni dan sebagainya. Benarkah pilihan pendidikan ini berkaitan dengan faktor gender? Pembahasan di bawah ini akan mencoba menganalisisnya.

Doreen Kimura melakukan studi menarik tentang diferensiasi seks (jenis kelamin) dalam fungsi belahan otak (kanan dan kiri). Fungsi belahan otak sering dikaitkan dengan stereotipe laki-laki dan perempuan yang bersumber dari trait theory mindset, yang mengungkapkan laki-laki berpikir logis, agresif, rasional, strategis, kompetitif, dan pembuat keputusan. Adapun perempuan lebih berpikir intuitif, emosional, spontan, submisif, dan kooperatif. Menurut teori otak ini, laki-laki seolah-olah memiliki dominasi pada belahan otak sebelah kiri yang menekankan pada bahasa (language), logika (logic), bilangan (number), matematika, urutan (sequence), dan kata (words). Sementara belahan otak kanan yang menekankan pada sajak (rhyme), irama (rhythm), musik (music), gambar (pictures), imajinasi (imagination), dan pola (patterns) lebih didominasi oleh perempuan. (Gordon Dryden and Jeannette Vos, 1993)

Beberapa studi yang dirujuk Gaguk Margono juga mengungkapkan hal sama. Perbedaan dominasi belahan otak pada laki-laki dan perempuan ini semakin menguatkan konstruk gender yang ada di masyarakat. Faktor biologis (genetik/kromosom, hormon, dan otak) menjadi alat pengabsahan perbedaan seks (laki-laki dan perempuan) dan gender (maskulin, feminin). Pada pilihan bidang dan pekerjaan yang diminati perempuan, fungsi belahan otak sangat berpengaruh. Perempuan biasanya lebih suka pada pekerjaan yang mengandung unsur relasi emosional dan pembentukan perasaan, seperti bidan, guru, pekerja seni, dan lain-lain. Kebanyakan perempuan kurang berminat pada masalah politik, lebih-lebih politik yang menggunakan cara-cara licik, munafik, dan intrik. Sikap tidak berminat ini disebabkan karena tindak politik kurang sesuai dengan nilai-nilai etis dan perasaan halus perempuan. Di tingkat sekolah, faktor belahan otak ini berpengaruh terhadap pilihan mata pelajaran yang diminati dan/atau tidak diminati oleh siswa laki-laki dan perempuan. Studi Margono yang mengacu studi-studi lain dari berbagai negara menyebutkan bahwa ada perbedaan hasil belajar matematika antara siswa laki-laki dan perempuan baik yang berasal dari desa, yakni 32,8(lk):31,8(pr) maupun kota, yakni 29,6(lk): 28,4(pr). Skor rata-rata hasil belajar matematika pada siswa laki-laki 
relatif lebih unggul daripada siswa perempuan. Beberapa penelitian tersebut memperkuat stereotipe bahwa matematika = laki-laki; suatu persepsi yang menunjukkan kecenderungan pilihan terhadap mata pelajaran merupakan cermin dan mengimplikasikan perbedaan gender dalam pilihan pendidikan.

Pernyataan di atas juga tampak pada hasil penelitian Mary Astuti yang mengevaluasi buku pelajaran matematika dan bahasa Indonesia SD, SLTP (SMP), dan SLTA (SMU). Astuti mengungkapkan bahwa gambar-gambar atau ilustrasi yang ditampilkan dalam buku matematika, 95\% adalah "figur laki-laki". Dari sudut pandang feminisme, gambar atau ilustrasi itu saja sudah menampakkan perspektif yang bias gender. Gambar mencerminkan "mental kolektif” yang dipersepsi dan dikonstruk oleh budaya patriarkhis. Ia menyiratkan 'pesan tersembunyi' seakan-akan perempuan tidak wajib belajar matematika karena hanya laki-laki yang berhak mempelajari. Hal ini belum ditelisik dari segi isi buku, misalnya dalam soal-soal matematika dengan cerita (terutama SD) selalu menyebutkan bahwa yang mempunyai tanah (sebagai aset ekonomis) adalah laki-laki. Dari segi ini, gambar dan isi suatu buku akan memberi image pada anak/siswa bahwa hanya laki-laki yang punya hak atas tanah, padahal perempuan juga punya hak yang sama atas tanah.

Pembedaan perlakuan antara murid perempuan dan murid laki-laki juga terjadi pada upacaraupacara yang digelar di sekolah. Anak laki-laki, karena suaranya keras, selalu dipilih sebagai pemimpin upacara. Sekolah tidak menyadari murid perempuan juga mampu bersuara keras, lantang, dan pantas menjadi pemimpin upacara. Semasa taman kanak-kanak pun, bentuk permainan sudah dibedakan untuk anak laki-laki dan perempuan. Pembedaan ini mungkin bukan menunjukkan perbedaan yang esensial, tetapi pembedaan berdasarkan kebiasaan belaka. Akan tetapi, image dan dampak dari pembedaan ini melekat pada pribadi anak. Lembaga pendidikan yang berfungsi sebagai konservasi (tempat pelestarian) dan inkulturisasi (penyemaian) nilai-nilai bagaimanapun akan dan masih menjadi alat efektif untuk sosialisasi nilai gender. Jika nilai-nilai yang dipraktekkan sekolah bias gender, anak-anak yang terlahir dari rahim pendidikan ini akan tetap memiliki pandangan yang bias gender.

Perbedaan gender dalam pendidikan juga tampak dalam hal pilihan jurusan yang diambil oleh laki-laki dan perempuan. Budi Rajab mengemukakan bahwa di tingkat SMU proporsi murid perempuan relatif lebih sedikit di jurusan IPA (Ilmu Pengetahuan Alam) dibanding di IPS (Ilmu Pengetahuan Sosial) dan Budaya. Alasan dalam soal ini pun kelihatannya berhubungan dengan peran dan stereotipe terhadap perempuan. Pertama, nilai rapor murid perempuan umumnya lebih rendah daripada murid laki-laki. Karena nilai rapor merupakan salah satu prasyarat masuk jurusan IPA, perempuan mengalami diskriminasi pilihan. Alasan kedua, anak perempuan memang ditekan untuk tidak memasuki jurusan IPA, karena bidang ini dianggap sebagai bidang khusus kaum laki-laki. Hal ini membuat perempuan takut untuk memilih jurusan yang dianggap bukan bidangnya. Akibatnya, mereka memilih jurusan IPS dan Budaya yang dianggap sesuai untuk mereka. Alasan ini pun terlalu berlebihan dan bertentangan dengan realitas bahwa sekolah tidak pernah memberikan persyaratan bahwa jurusan IPA hanya khusus untuk laki-laki dan IPS atau Budaya diprioritaskan untuk perempuan.

Pada tingkat SMK (Sekolah Menengah Kejuruan), perbedaan gender juga tidak bisa dipandang semata-mata karena perbedaan perlakuan sekolah. Ace \& Idris mengungkapkan, bahwa dari segi jumlah siswa, antara perempuan dan laki-laki, bisa saja dikatakan setara menurut gender. Akan tetapi, dilihat berdasarkan jurusan bisa dikatakan terjadi kesenjangan gender bila jurusan yang dipilih perempuan merupakan jurusan yang berhubungan dengan pekerjaan sektor domestik. Pemilihan program/jurusan di SMK ini berkaitan dengan pandangan masyarakat yang diasumsikan berdasarkan kecocokan antara program studi dengan jenis kelamin. Ukuran yang dipakai dalam menentukan kecocokan adalah ukuran pantas atau tidak pantas, yang seolah-olah ada sangsi sosial yang menuntut orang tua siswa untuk menyesuaikan cita-cita anaknya dengan tuntutan budaya dan sistem nilai masyarakat yang diskriminasi gender atau bias gender. Konsekuensinya dalam pemilihan program studi di SMK, program studi yang dipersepsikan oleh masyarakat kurang pantas untuk perempuan akan didominasi oleh laki-laki. Program keahlian yang didominasi laki-laki tersebut misalnya 
kelompok program keahlian teknologi dan pertanian. Sedangkan perempuan lebih memilih kelompok program keahlian yang dianggap lebih pantas untuk perempuan, seperti program keahlian bisnis dan manajemen dan program keahlian seni dan kerajinan seperti jurusan tata boga, tata busana, tata rias, dan sejenisnya.

Pilihan perempuan pada bidang ini juga berkaitan dengan masalah "kemana lulusan SMK tersebut memasuki lapangan kerja" yang memposisikan perempuan pada bidang-bidang yang dianggap lebih tepat dengan sifat perempuan yang ulet, rajin, telaten, dan bayarannya murah. Jadi, pilihan jurusan bagi perempuan tidak berdiri sendiri, melainkan berhubungan dengan "pandangan dunia luar" terhadap pekerjaan perempuan. Selama dunia industri masih memposisikan pekerja perempuan seperti itu, pilihan perempuan (dan orang tua) yang tercermin dalam pilihan jurusan di SMK sulit berubah. Hal yang sama menimpa laki-laki. Adanya asumsi perbedaan kemampuan intelektual dan keterampilan antara laki-laki dan perempuan memperkuat bias gender tersebut.

Tabel di bawah ini menunjukkan bahwa siswa laki-laki di SMK lebih memilih dan mendominasi program studi Pertanian dan Kehutanan yaitu sebesar 70,26\%, sedangkan perempuan sebesar 29,74\%. Program keahlian lain yang didominasi laki-laki adalah Teknologi Industri sebesar $81,54 \%$ sedangkan perempuan hanya $18,46 \%$. Di sisi lain perempuan mendominasi program studi Manajemen Bisnis sebesar 64,56\% dan 35,44\% untuk laki-laki. Program studi Seni dan Kerajinan sebesar 58,84\% untuk perempuan dan $41,16 \%$ laki-laki. Dua program studi lainnya menunjukkan keseimbangan antara laki-laki dan perempuan yaitu program studi Pekerjaan Sosial sebesar 52,64\% laki-laki dan 47,36\% perempuan, dan program studi Kepariwisataan yaitu 49,71\% laki-laki dan 50,29 $\%$ perempuan.

Tabel 5: Proporsi Siswa Menurut Gender dan Jurusan di SMK Tahun 2000-2001

\begin{tabular}{|l|l|r|c|r|r|r|}
\hline \multirow{2}{*}{ No } & \multirow{2}{*}{ Program Studi } & \multicolumn{2}{|c|}{ Laki-Laki } & \multicolumn{2}{c|}{ Perempuan } & \multirow{2}{*}{ Jumlah } \\
\cline { 3 - 6 } & & Jumlah & Prosen (\%) & Jumlah & Prosen (\%) & \\
\hline 1 & Pertanian dan Kehutanan & 31.234 & 70,26 & 13.221 & 29,74 & 44.455 \\
\hline 2 & Teknologi & 658.235 & 81,54 & 149.036 & 18,46 & 807.271 \\
\hline 3 & Bisnis dan Manajemen & 332.485 & 35,44 & 605.591 & 64,56 & 938.076 \\
\hline 4 & Pekerjaan Sosial & 6.381 & 52,64 & 5.742 & 47,36 & 12.123 \\
\hline 5 & Kepariwisataan & 52.882 & 49,71 & 53.492 & 50,29 & 106.374 \\
\hline 6 & Seni dan Kerajinan & 10.553 & 41,16 & 15.085 & 58,84 & 25.638 \\
\hline & Jumlah & $\mathbf{1 . 0 9 1 . 7 7 0}$ & $\mathbf{5 6 , 4 5}$ & $\mathbf{8 4 2 . 1 6 7}$ & $\mathbf{4 3 , 5 5}$ & $\mathbf{1 . 9 3 3 . 9 3 7}$ \\
\hline
\end{tabular}

Sumber: Pusat Data \& Informasi Pendidikan Balitbang Depdiknas, 2001

(Dikutip dari Ace\&Idris, 2004)

Data yang dikemukakan oleh Suleeman tentang pilihan fakultas/jurusan pada tingkat perguruan tinggi seharusnya difahami dari perspektif harapan orang tua (atau anak) yang dipengaruhi faktor budaya (gender). Data dari Universitas Indonesia tentang jumlah mahasiswa menurut gender dan fakultas tahun ajaran 1991/1992 menunjukkan bahwa mahasiswa perempuan lebih banyak memilih pada fakultas-fakultas yang "lebih dekat dengan bidang dan peranan perempuan" seperti Fakultas Kedokteran Gigi (FKG) 82\%, Fakultas Sastra (FS) 63\%, dan Fakultas Psikologi (FPsi) 75\%. Hal yang sama juga berlaku di jurusan-jurusan yang ada di bawah fakultas. Jurusan yang mempunyai jumlah mahasiswa perempuan lebih banyak adalah Keperawatan di Fakultas Kedokteran (71\%), Biologi (66\%), dan Farmasi (66\%) di FMIPA, Komunikasi (71\%), Kesejahteraan Sosial (65\%), dan Antropologi (68\%) di FISIP. 
Kuatnya faktor budaya atas pilihan pendidikan ini juga dikemukakan Ester Boserup. Pada masyarakat yang anak perempuannya diajarkan bahwa mereka lebih rendah daripada anak lakilakinya, kata Boserup, dengan sendirinya anak laki-laki akan mendapatkan pendidikan yang lebih baik sehingga lebih terampil atau lebih pintar daripada anak perempuan. Karena mendapat pendidikan lebih baik, realistis saja jika laki-laki akan masuk pasaran kerja yang terbuka lebih mudah ketimbang anak perempuan. Sementara perempuan yang 'dinomorduakan' dalam memperoleh akses pendidikan, dengan sendirinya akan memilih jurusan di sekolah atau jenis pekerjaan yang sesuai dengan mereka. Menurut Boserup, hanya minoritas kecil yang ingin bersaing terang-terangan dengan laki-laki di dalam bidang pendidikan atau pekerjaan yang menurut konsensus umum sesuai dengan perempuan. (Ester Boserup, 1984).

\section{Realitas Kesetaraan Gender dalam Pendidikan}

Kesetaraan gender dalam bidang pendidikan dipandang sangat penting karena sektor pendidikan merupakan sektor yang paling strategis untuk memperjuangkan kesetaraan gender. Nilai strategis ini akan berjalan dengan asumsi bahwa tidak ada bias gender dalam kebijakan-kebijakan pemerintah khususnya dalam bidang pendidikan. Artinya, kesempatan dan peluang untuk mendapatkan akses pendidikan dalam kerangka peningkatan potensi sumberdaya manusia (SDM) harus terbuka seluasluasnya bagi laki-laki maupun perempuan, dengan peluang yang sama.

Upaya pemerintah dalam mengembangkan SDM melalui pendidikan, sebagaimana disinggung di muka terus dilakukan, tetapi mengalami hambatan pada saat krisis ekonomi melanda Indonesia. Dampak krisis bukan saja pada daya beli masyarakat, tetapi juga berdampak pada kemampuan orang tua untuk membiayai sekolah anak-anaknya. Berdasarkan hasil studi Ace Suryadi dkk. (1998), terungkap bahwa walaupun kecil, APM (Angka Partisipasi Murni) tingkat SD dan SLTP menurun hingga 93,7\% di SD dan 55,05\% di SLTP. Penurunan APM ini disebabkan oleh putus sekolah yang meningkat dan jumlah pendaftar sekolah menurun. Kondisi penurunan APM tersebut bila dibandingkan dengan APM-SD mencapai 94,96\% dan APM di SLTP mencapai 55,92\%. (Ace Suryadi , 1997).

Kesempatan memperoleh pendidikan untuk perempuan pada tahun yang sama, 1998, juga relatif rendah dibandingkan dengan laki-laki. APM perempuan di SD pada tahun 1998/1999 berjumlah 93\% dibanding laki-laki yang mencapai 97,1\%. Di tingkat SLTP APM perempuan adalah 54,7\%, sedangkan laki-laki 57,1\%. Pada tingkat SLTA APM perempuan 29,8\%, sementara APM laki-laki 30,17\%. Meskipun perbandingan angka ini rendah, angka penduduk perempuan usia sekolah (SLTA) lebih tinggi ketimbang laki-laki. Ketimpangan angka ini boleh jadi berkaitan dengan pilihan orang tua yang lebih memprioritaskan anak laki-lakinya ketimbang anak perempuannya di saat kondisi ekonomi keluarga tidak memungkinkan menyekolahkan keduanya. Hal ini sejalan dengan logika 'faktor investasi' sebagaimana disinggung di bagian terdahulu. Pada saat orang tua harus memilih: siapakah yang harus disekolahkan, anak laki-laki atau perempuan, maka pilihan jatuh pada anak laki-laki. Pertimbangannya, anak perempuan tidak perlu sekolah tinggi-tinggi toh pada akhirnya mengabdi kepada suami sebagai istri dan ibu bagi anak-anak yang akan dilahirkan kelak. Dalam hal ini faktor budaya (gender) bertitik singgung dengan kondisi ekonomi atau kemampuan orang tua menyekolahkan anaknya. Dengan kata lain, kemiskinan keluarga amat berpengaruh terhadap pilihan orang tua dalam menyekolahkan anak perempuan.

Setelah hampir empat tahun krisis ekonomi berjalan, APM SD dan SLTP naik kembali menjadi 95,51\%. Peningkatan APM ini menunjukkan bahwa dampak krisis ekonomi terhadap pendidikan mulai berkurang dimana anak putus sekolah mulai berkurang dan angka melanjutkan ke SLTP mengalami peningkatan lagi. Apabila dilihat dari kesetaraan gender untuk APM-SD masih sedikit ada kesenjangan yaitu $96,64 \%$ untuk laki-laki dan 94,34\% untuk perempuan. Hal ini sangat mungkin berkaitan dengan jumlah penduduk usia sekolah SD yang lebih banyak laki-laki. Pada tingkat SLTP kesenjangan gender sudah tidak ditemui lagi. APM-SLTP untuk laki-laki dan perempuan sudah seimbang yaitu masing-masing 56,62\% dan 56,30\%, walaupun jumlah penduduk usia sekolah SLTP 
perempuan lebih sedikit. Akan tetapi, APM-SLTA kembali ada kesenjangan dimana laki-laki berjumlah 34,06\% dan perempuan 31,14\%.

Angka-angka yang dikemukakan Ace \& Idris menunjukkan kecenderungan bahwa semakin tinggi tingkat pendidikan, semakin kecil angka partisipasi masyarakat dalam mengikuti pendidikan. Hal ini lebih disebabkan karena semakin tinggi tingkat pendidikan, semakin tinggi juga biaya yang harus dikeluarkan, sedangkan kemampuan masyarakat belum seluruhnya mampu membiayai pendidikan. Persoalan ekonomi yang pelum pulih selama didera krisis sejak 1998 turut memperlemah daya beli masyarakat, sementara kebutuhan sehari-hari (subsisten) mereka jauh lebih mendesak ketimbang mempertimbangkan pendidikan anak. Tidak heran bila dalam situasi reses banyak di kalangan masyarakat yang merindukan biaya pendidikan ditangggung sepenuhnya oleh pemerintah alias pendidikan gratis. Selama masa kampanye Presiden dan Legislatif 2004, pendidikan gratis bagi SD dan SLTP pernah dijadikan salah satu isu populis oleh para kontestan atau calon anggota legislatif. Bahkan hingga 2005 isu pendidikan gratis ini kembali mengemuka. Kebijakan pendidikan gratis ditengarai akan disambut gembira oleh sekitar 70 persen penduduk Indonesia yang berada pada lapis bawah, anak-anak miskin di kota dan desa, dan yang drop out karena hambatan biaya.

Kemampuan ekonomi masyarakat juga berpengaruh terhadap naik turunnya partisipasi pendidikan pada jenjang pendidikan sekolah menengah dan pendidikan tinggi. APK (Angka Partisipasi Kasar) SLTA lebih kecil bila dibandingkan APK-SLTP. Pada tahun 2001, berdasarkan laporan Pusat Data dan Informasi Pendidikan Balitbang-Depdiknas, APM-SLTA sebesar 32,62 dan APK-SLTA mencapai 40,67\%. Sedangkan APK-PT lebih kecil lagi yaitu sebesar 11,54\%. Kecilnya APM dan APK untuk SLTA dan PT, selain disebabkan karena masih terbatasnya jumlah lembaga pendidikan SLTA dan PT, dan kemampuan ekonomi masyarakat, juga penduduk usia sekolah SLTA dan PT sudah banyak yang memilih bekerja dibanding sekolah.

Bila dilihat komposisinya berdasarkan kesetaraan gender di tingkat sekolah menengah dan pendidikan tinggi, keterlibatan perempuan juga menurun. Jika APK laki-laki di SLTA mencapai 41,50\%, perempuan hanya 39,83\%. Begitu juga APK laki-laki di PT sebesar 12,79\%, perempuan masih 10,22\%. Jumlah ini semakin memperkuat asumsi bahwa semakin tinggi jenjang pendidikan, kesempatan perempuan semakin mengecil. Bila dibandingkan dengan kondisi sebelum krisis tahun 1998, walaupun masih ada kesenjangan untuk APK-SLTA tetapi mengalami peningkatan sebesar $3,00 \%$, sedangkan APK pendidikan tinggi selain mengalami peningkatan sekitar 1,00\%, juga angka kesenjangan semakin mengecil. Apakah ini berlaku di semua jenis pendidikan, seperti madrasah atau sekolah kejuruan? Masalah ini akan dibahas pada bab berikutnya.

Walaupun angka partisipasinya lebih rendah, perempuan lebih mampu bertahan dibandingkan dengan laki-laki. Angka putus sekolah siswa perempuan selalu lebih kecil, khususnya pada SMU, SMK dan PT. Siswa perempuan juga lebih banyak yang dapat menyelesaikan sekolah sampai lulus dibandingkan dengan lawan jenisnya. Gejala-gejala tersebut menunjukkan bahwa peserta didik perempuan lebih optimal dalam memanfaatkan kesempatan belajar.

Angka bertahan menunjukkan tingkat persentase peserta didik yang masuk sekolah di tingkat pertama dan mampu terus bertahan hingga mereka dapat menyelesaikan pendidikannya sampai lulus sekolah. Berdasarkan data Balitbang Depdiknas, angka bertahan menurut gender menunjukkan gejala yang menarik untuk diteliti. Pertama, ada kecenderungan angka bertahan berlawanan dengan angka partisipasi (APK). Jika APK menunjukkan gejala semakin tinggi jenjang pendidikan semakin kecil partisipasinya, angka bertahan justru sebaliknya. Semakin tinggi jenjang pendidikan semakin besar angka bertahannya. Kondisi ini menunjukkan bahwa mulai jenjang pendidikan SLTP, siswa yang masuk ke lembaga persekolahan cenderung mampu bertahan sampai lulus. Angka pada tabel di bawah menunjukkan dengan jelas bahwa persentase angka bertahan SD lebih rendah dibandingkan SLTP dan SMU.

Kedua, bila dilihat dari perbandingan gender, ternyata angka bertahan perempuan lebih tinggi ketimbang laki-laki pada semua jenjang pendidikan (tabel 6). Dipandang dari segi efisiensi, dapat dikatakan pendidikan untuk perempuan lebih efisien karena angka bertahan perempuan lebih tinggi. 
Artinya, secara umum siswa perempuan lebih mampu menyelesaikan studinya dengan baik, dengan indikator siswa perempuan yang putus sekolah dan mengulang kelas lebih sedikit ketimbang lawan jenisnya.

Tabel 6: Angka Bertahan Menurut Gender Tahun 2000-2001

\begin{tabular}{|c|l|c|c|c|}
\hline \multirow{2}{*}{ No } & \multicolumn{1}{|c|}{ Jenjang Pendidikan } & \multicolumn{2}{|c|}{ Jenis Kelamin } & \multirow{2}{*}{ Jumlah } \\
\cline { 3 - 5 } & & Laki-Laki & Perempuan & \\
\hline 1 & Sekolah Dasar (SD) & 74.36 & 80.02 & 77.05 \\
\hline 2 & Sekolah Lanjutan Pertama (SLTP) & 94.29 & 95.84 & 95.02 \\
\cline { 2 - 5 } & Sekolah Menengah (SM) & 92.50 & 97.62 & 94.93 \\
\hline & a. Sekolah Menengah Umum (SMU) & 92.59 & 98.82 & 95.71 \\
& b. Sekolah Menengah Kejurusan (SMK) & 92.39 & 95.54 & 93.70 \\
\hline
\end{tabular}

Sumber: Pusat Data \& Informasi Pendidikan Balitbang Depdiknas, 2001

(Dikutip dari Ace\&Idris, 2004)

Angka bertahan yang tinggi ditunjukkan dengan angka kelulusan yang tinggi dan sekaligus menggambarkan tingkat efisiensi yang tinggi. Dalam konteks ini, kesetaraan pendidikan juga bisa diamati dari seberapa besar angka kelulusan siswa laki-laki dan perempuan. Menurut Ace \& Idris, angka kelulusan merupakan salah satu indikator yang menunjukkan tingkat efisiensi pendidikan dari segi siswa. Angka kelulusan yang tinggi menggambarkan efisiensi pendidikan yang tinggi pula. Tingginya angka kelulusan menggambarkan keberhasilan siswa dalam menempuh ujuan akhir sekolah. Jadi indikator angka kelulusan sangat berkaitan dengan indikator angka bertahan. Perbedaannya, angka kelulusan hanya menghitung jumlah siswa tingkat akhir dan jumlah siswa berhasil lulus. Sedangkan angka bertahan memperhitungkan angka mengulang kelas, angka putus sekolah dan angka kelulusan. Angka kelulusan perempuan adalah indikator yang menunjukkan persentase perempuan yang lulus terhadap jumlah siswa perempuan yang mengikuti ujian akhir.

Tabel 6: Angka Kelulusan Menurut Gender Tahun 2000-2001

\begin{tabular}{|c|c|c|c|c|c|c|c|}
\hline \multirow{2}{*}{$\mathrm{NO}$} & \multirow{2}{*}{$\begin{array}{c}\text { JENJANG } \\
\text { PENDIDIKAN }\end{array}$} & \multicolumn{3}{|c|}{ LULUSAN } & \multicolumn{3}{|c|}{ ANGKA KELULUSAN } \\
\hline & & Laki-Laki & Perempuan & Jumlah & Laki-Laki & Perempuan & Jumlah \\
\hline 1 & Tingkat SD & 2.040 .417 & 1.960 .348 & 4.000 .765 & 95,88 & 96,18 & 96,03 \\
\hline $\mathrm{a}$ & SD & 1.842 .574 & 1.770 .268 & 3.612 .842 & 97,80 & 97,81 & 97,81 \\
\hline $\mathrm{b}$ & MI & 197.843 & 190.080 & 387.923 & 81,07 & 83,24 & 82,12 \\
\hline 2 & Tingkat SLTP & 1.446 .893 & 1.383 .834 & 2.830 .727 & 90,83 & 93,28 & 92,01 \\
\hline $\mathrm{a}$ & SLTP & 1.168 .862 & 1.117 .920 & 2.286 .782 & 90,73 & 94,28 & 92,43 \\
\hline $\mathrm{b}$ & MTs & 278.031 & 265.914 & 543.945 & 91,24 & 89,33 & 90,30 \\
\hline 3 & Tinglet CM & & & & & & \\
\hline a & 1ingKat SIV & 432336 & $1 / 4.944$ & 800512 & $93, / 8$ & 94,31 & $\begin{array}{l}94,00 \\
05,07\end{array}$ \\
\hline $\begin{array}{l}a \\
b\end{array}$ & MA & $\begin{array}{r}72.188 \\
72.180\end{array}$ & 76.503 & 148.691 & 84,31 & 84,59 & 84,46 \\
\hline $\mathrm{c}$ & SMK & 329.547 & 240.265 & 569.812 & 94,63 & 96,27 & 95,31 \\
\hline
\end{tabular}

Sumber: Diadaptasi dari Ace \& Idris, 2004; Pusat Data \& Informasi Pendidikan BalitbangDepdiknas Tahun 2001 
Berdasarkan indikator seperti terlihat pada tabel di atas, siswa perempuan lebih banyak yang bisa menyelesaikan studi sampai lulus dibandingkan dengan siswa laki-laki. Angka kelulusan siswa perempuan lebih besar hampir pada semua jenjang pendidikan, kecuali MTs untuk tingkat dasar. Secara keseluruhan angka kelulusan siswa perempuan selalu lebih besar dibanding laki-laki. Angka kelulusan siswa perempuan pada tingkat SD sebesar 96,18\%, SLTP 93,28\%, SMU 95,22\%, SMK 96,27\%, dan MA sebesar 84,59\%. Adapun angka kelulusan siswa laki-laki lebih kecil hampir pada semua jenjang pendidikan, pada tingkat SD sebesar 95,88\%, SLTP sebesar 90,83\%, SMU sebesar 94,91\% SMK sebesar 94,63\% dan MA sebesar 84,31\%. Angka kelulusan yang didominasi oleh lakilaki hanya terjadi pada MTs yaitu sebesar $91,24 \%$ untuk laki-laki dan 89,33\% perempuan.

Apabila dilihat dari segi jumlah penduduk usia sekolah secara keseluruhan, jumlah perempuan memang lebih kecil dibandingkan jumlah laki-laki. Pada tingkat SD tahun 2000-2001 misalnya, jumlah perempuan mencapai 12.434 .448 orang, sedangkan laki-laki 12.831 .552 orang. Begitu juga jumlah usia sekolah perempuan pada tingkat SLTP berjumlah 6.354.867 orang dan laki-laki 6.547.033 orang. Akan tetapi, perbedaan ini tidak terlalu signifikan atau relatif setara berdasarkan gender. Demikian juga apabila ditambah dengan proporsi angka melanjutkan perempuan yang lebih kecil, jumlah siswa perempuan di sekolah akan menjadi lebih kecil dibanding jumlah siswa laki-laki. Hal ini memperkuat dugaan bahwa program Wajib Belajar Pendidikan Dasar 9 Tahun yang telah dicanangkan pemerintah sejak tahun 1994 sudah mulai berhasil. Namun demikian, angka melanjutkan untuk semua jenjang pendidikan hampir selalu perempuan lebih kecil dari laki-laki. Perbandingan yang cukup mencolok, adalah proporsi perempuan yang melanjutkan dari lulusan SMP yang masuk SMK dan lulusan SMU yang masuk ke Perguruan Tinggi. Kondisi yang sebaliknya terjadi pada proporsi siswa perempuan yang masuk SMU tahun 2001 lebih besar dibanding laki-laki.

Tabel 8: Angka Melanjutkan Menurut Gender Tahun 2000-2001

\begin{tabular}{|c|l|r|r|r|r|c|c|}
\hline \multirow{2}{*}{ No } & \multirow{2}{*}{ Jenjang Pendidikan } & \multicolumn{3}{|c|}{ Siswa/Mahasiswa Baru } & \multicolumn{3}{c|}{ Angka Melanjutkan } \\
& & Laki-Laki & Prempuan & \multicolumn{1}{c|}{ Jumlah } & Laki-Laki & Perempuan & Jumlah \\
\hline 1 & SD ke SLTP & 1.340 .793 & 1.264 .620 & 2.605 .413 & 72.77 & 71.44 & 72.12 \\
\hline 2 & SLTP ke SM & 891.728 & 813.149 & 1.704 .877 & 76.29 & 72.74 & 74.75 \\
& a. SLTP ke SMU & 496.253 & 515.801 & 1.012 .054 & 42.46 & 46.14 & 44.26 \\
& b. SLTP ke SMK & 395.475 & 297.348 & 692.823 & 33.83 & 26.60 & 30.30 \\
\hline 3 & SM ke PT *) & 391.501 & 312.495 & 703.996 & 51.39 & 44.74 & 48.21 \\
\hline
\end{tabular}

*) Diploma, Sarjana, LPTK, Non-LPTK

Sumber: Diadaptasi dari Ace \& Idris, 2004; Pusat Data \& Informasi Pendidikan BalitbangDepdiknas Tahun 2001

Berdasarkan komposisi menurut gender, angka melanjutkan perempuan SD ke SLTP relatif seimbang yaitu sebesar 72,77\% laki-laki dan 71,44\% perempuan. Angka melanjutkan lulusan SLTP ke SMA sebesar 76,29\% laki-laki dan 72,74\% perempuan, sedangkan angka melanjutkan lulusan SMA ke Perguruan Tinggi tingkat kesenjangannya cukup besar yaitu 51,39\% laki-laki dan 44,74\% perempuan.. Kesenjangan yang cukup besar juga terjadi pada lulusan SLTP yang melanjutkan ke SMK, yaitu laki-laki sebesar 33,83\% dan perempuan 26,60\%. Kesenjangan ini tampaknya merupakan suatu gejala yang dalam kajian feminisme disebut stereotipe (pelabelan) perempuan dalam pendidikan. Pelabelan ini muncul karena masih kuatnya konotasi dalam masyarakat bahwa SMK, khususnya dalam program keahlian teknologi, dianggap lebih sesuai untuk laki-laki daripada untuk perempuan. Kecenderungan ini memperkuat anggapan bahwa pilihan pendidikan bagi perempuan belum sepenuhnya setara gender. 


\section{Penutup}

Uraian di atas menggambarkan bahwa meskipun pembangunan pendidikan menampakkan gejala perbaikan dari tahun ke tahun, pandangan masyarakat terhadap gender tidak secepat itu dapat berubah dan diubah. Kuatnya sistem nilai dan konstruk budaya yang belum merepresentasikan kesetaraan gender turut berpengaruh terhadap pola pendidikan persekolahan. Angka partisipasi, angka kelulusan, pilihan jurusan dan program studi, serta kemungkinan akses terhadap pekerjaan setelah tamat dari sekolah mencerminkan seberapa tinggi kesadaran masyarakat mengenai perlunya kesetaraan gender. Sepanjang konstruk budaya masyarakat masih membedakan peran dan posisi anak laki-laki dan perempuan, sepanjang itu pula pengaruhnya terhadap bentuk dan pola pendidikan persekolahan. Tampaknya butuh waktu panjang untuk memperjuangkan kesetaraan dan keadilan gender dalam pendidikan.

\section{Daftar Pustaka}

Apriadi, "Memahami Kesetaraan Gender di Madrasah", Seri Informasi Pendidikan Islam di Indonesia, no. 12, Jakarta: EMIS Ditperta Depag RI, 2001.

Arivia, Gadis, "Kebijakan Publik dalam Pendidikan: Sebuah Kritik dengan Perspektif Gender", Jurnal Perempuan, No. 23, 2002.

Astuti, Mary, "Pendidikan Berperspektif Gender”, dalam Basis, no. 07-08, Juli-Agustus 2000.

Azkiyah, Nurul, "Keterkaitan Pendidikan Formal Perempuan dan Dunia Pembangunan", Jurnal Perempuan No. 23, Mei 2002. Tulisan ini merupakan ringkasan dari Thesis Master penulis berjudul asli “The Relationship Between Women's Formal Education and Socio-Economic and Political Development for Them in Indonesia in the Period of 1980-2000" di University of York, United Kingdom (Inggris) dalam bidang Gender and Development.

Bank Dunia (World Bank Report) 1996 (Early Child Development in Indonesia, Jakarta: 1996.

Bappenas bekerjasama dengan Women's Support Project II-CIDA, Analisis Gender dalam Pembangunan Pendidikan, Jakarta: 2001.

Biro Pusat Statistik, tentang “Perempuan dan Laki-Laki di Indonesia, Jakarta: 1995.

Boserup, Ester, Peranan Wanita dalam Perkembangan Ekonomi, Jakarta: Yayasan Obor Indonesia, 1984.

Darmaningtyas, "Kemungkinan Pendidikan Gratis”, Kompas, 22 Juni 2005.

Dryden, Gordon and Jeannette Vos, The Learning Revolution, Auckland: Profile Books, 1993.

E. Boserup, Women's Role in Economic Development, terjemahan Indonesianya berjudul Peranan Wanita dalam Perkembangan Ekonomi,Jakarta: Yayasan Obor Indonesia, 1984.

Gaduh, Arya Budhisastra, "Pendidikan di Indonesia Sebelum dan Semasa Krisis", Analisis CSIS, Tahun XXIX/2000, No.3.

"Juklak Pendidikan Dasar Gratis Buka Peluang Sekolah Pungut Biaya", Kompas, 22 Juni 2005. 
Juoro, Umar, "Pendidikan dan Pembangunan di Asia", Prisma 1/1990.

“Kesenjangan Gender dalam Pendidikan Mulai Berkurang”, Kompas 13 Mei 2005.

“Kesetaraan Gender Menentukan Pencapaian MDG”, Kompas, 14 Juli 2003.

“Kesetaraan Gender Menentukan Pencapaian MDG”, Kompas, 17 Juli 2003.

Kimura, Doreen, "Sex Differences in the Brain", dikutip dari Gaguk Margono, "Perbedaan Gender dalam Matematika", Jurnal Perempuan, no. 23.

MM Billah, "Dari Paradigma Instrumentalistis ke Paradigma Alternatif", Pesantren, No. 3/Vol V/1988.

Rajab, Budi, "Pendidikan Sekolah dan Perubahan Kedudukan Perempuan", Jurnal Perempuan No. 23, Mei 2002.

St Kartono, “Mengajarkan Kesetaraan Gender”, Kompas 10 Pebruari 2003.

Suleeman, Evelyn, "Pendidikan Wanita Indonesia", T.O Ihromi (Peny.), Kajian Wanita dalam Pembangunan, Jakarta: Yayasan Obor Indonesia, 1995.

Suparno, Ana Suhaenah, "Wanita dan Pendidikan: Kasus Indonesia”, dalam HM Atho' Mudzhar, dkk (Ed.), Wanita dalam Masyarakat Indonesia, Yogyakarta: Sunan Kalijaga Press, 2001.

Suryadi, Ace \& Ecep Idris, Kesetaraan Gender dalam Bidang Pendidikan, Bandung: Genesindo, 2004.

Tilaar, HAR., Lima Puluh Tahun Pembangunan Pendidikan Nasional 1945-1995: Sebuah Analisis Kebijakan, Jakarta: Grasindo, 1995.

World Bank (1998), Education in Indonesia: From Crisis to Recovery, dikutip dari Gaduh, "Pendidikan di Indonesia", Analisis CSIS. 